\title{
MACROECONOMIC TIME SERIES AFFECTING THE MINIMUM AND AVERAGE WAGES OF V4 COUNTRIES
}

\author{
Lucie Meixnerová1, Michal Krajňák ${ }^{2}$
}

\footnotetext{
1 Silesian University in Opava, School of Business Administration in Karviná, Department of Business Economics and Management, Czech Republic, ORCID: 0000-0003-2649-5526, meixnerova@opf.slu.cz;

2 VSB-Technical University of Ostrava, Faculty of Economics, Department of Accounting and Taxes, Czech Republic, ORCID: 0000-0003-4924-3583, michal.krajnak@vsb.cz.
}

\begin{abstract}
The study deals with the evaluation of the impact of macroeconomic indicators such as gross domestic product, unemployment, the implicit tax rate on labour and the consumer price index on the minimum and average wages in the countries of the Visegrad Four. The set of input analysed data is obtained from databases of national statistical offices, the Organisation for Economic Cooperation and Development and Eurostat. Since the minimum wage is influenced by state intervention, it is an intervention in the market mechanism and its costs are borne primarily by employers, it is an important indicator in assessing the impacts in the payroll field. Employers have a direct impact on the level of the average wage. From the results of derived VAR models, it cannot be argued that short-term relations in selected countries show the same regularities. However, common characteristics can be found between macroeconomic indicators and minimum and average wage. The results of the article show that if the endogenous variable is the minimum wage, there are no significant dependencies between the above-mentioned indicators. Each of the analysed countries has its own instrument for regulating the minimum wage independent of macroeconomic factors, which has been confirmed. If an average wage indicator is an endogenous variable, this variable has both a positive and negative impact on the remaining indicators analysed. The implicit tax rate on labour was evaluated as the most statistically significant indicator affecting the average wage. The results of the testing between the minimum or average wage and the macroeconomic indicators in the sense of Granger causality confirmed the fact that the development of selected macroeconomic indicators contributes to an increase in the accuracy of the forecast of the evolution of the average wage in the examined countries.
\end{abstract}

Keywords: Average wage, minimal wage, implicit tax rate.

JEL Classification: C20, C50, H24, J31, M21.

APA Style Citation: Meixnerová, L., \& Krajňák, M. (2020). Macroeconomic Time Series Affecting the Minimum and Average Wages of V4 Countries. E\&M Economics and Management, 23(4), 4-22. https://doi.org/10.15240/tul/001/2020-4-001

\section{Introduction}

The minimum wage institute was established at the turn of the 19th and 20th century in the AngloSaxon countries. Its purpose was to ensure the protection of the workforce. The minimum wage ensures that the labour market wage cannot fall below the determined level, which takes the form in accordance with the economic and political conditions of the country concerned (Dube et al., 2010). The determined level of the minimum wage results either from the tripartite act, which is made up of representatives of government, employers and trade unions or is enacted in relation to a percentage of the average wage level. Lopresti and Mumford (2016) mention that setting a minimum wage is a very complex problem, as its value is related to the price of labour that affects employers' competitiveness. The minimum wage affects not only the part of the employer but also the 
employee, as employees want to receive fair remuneration for their work that will ensure them the required standard of living. The minimum wage is the lowest level of wage that the employer is obliged to provide for the work done, regardless of its complexity, type, quantity, quality, or as a performance resulting from the employment relationship. Another reason for the existence of the minimum wage, in addition to the protective function of employees, is to ensure that employees are motivated to work rather than benefit from social benefits from the state.

The article aims to evaluate the impact of selected indicators on the development of minimum and average wages in the V4 countries - the Czech Republic, Slovakia, Poland and Hungary. Due to the fact that the minimum wage is set at a universal rate for the whole country, its impacts in the regions can be significantly differentiated. The regional impacts are not addressed in the study. The selected macroeconomic indicators, for which a significant impact on the development of the minimum and the average wage was concluded, are the implicit tax rate on labour, unemployment rate, gross domestic product and consumer price index describing the general economic conditions of the country. Their expected effect is given in formulas (2) and (4). The first part of the text deals with an overview of research studies assessing the impact of the selected indicator on the development of the minimum and average wage. The second part of the article provides an overview of the methods used for solutions and information about the data sources that are analysed later on. The crucial part of the text is formed by the analysis of selected dependencies between the minimum or average wage and selected indicators in the V4 countries. In conclusion, the results achieved are summarized and further research opportunities in this field are proposed, as well as possible limitations of current research.

\section{Literature Review}

The minimum wage is irregularly at the forefront of public debates about income inequality. While the subsequent proposal to increase the Czech minimum wage regularly gets stuck until the end of the year for governmental tripartite negotiations, countries such as Slovakia, Poland and Hungary have it already processed in the legislation in the forecast for several years (Statistical Office of the Slovak Republic, 2020; Czech Statistical Office, 2020; Statistics Poland, 2018; Hungarian Central Statistical Office, 2020).

The apparent political importance of the development of minimum wages has created large-scale economic studies and literature on the impact of minimum wages on employment level, wages distribution and other labour market outcomes. However, there is little economic theory about the suitability of the minimum wage in relation to other income redistribution instruments, such as progressive income taxation. As a result, a satisfactory answer has not yet been provided to the question in this study: How the minimum wage adapts to the overall wage development in relation to the effects of macroeconomic indicators that must be taken into account when implementing the mechanism for regulating the minimum wage. Political debates concerning minimum wage reforms tend to be highly contentious. A remarkable example, on the one hand, is the higher minimum wage supported by public and political debates. One important reason for this debate is that both advocates and opponents make arguments that are either subjective or empirically countervailable. Advocates of the minimum wage emphasize distribution benefits because they increase the incomes of low-skilled workers. The estimation of these distribution effects, however, requires an internal political judgment that economists have nothing to say about. Opponents of the minimum wage emphasize that it is reducing employment. Factors which influence minimum wages are macroeconomics indicators, i.e. unemployment, gross domestic products or average wage (Blais et al., 1989). The analysis of the dependence of selected indicators on the minimum wage has been the subject of many research studies carried out both in the environment of the Czech Republic, the Slovak Republic, Poland and Hungary.

Gross domestic product has higher influence on the average wage than on the minimum wage. The positive effects of growth minimal wages on average wages and gross domestic product are confirmed by Pernica and Janáč (2015), who also emphasize that of the analysed V4 countries, the lowest minimum wage in the Czech Republic had lowest minimum wages at the time the study 
was conducted. On the contrary, Balcar and Gotwald (2016), who examined which factories affect wages in the Czech Republic between 2008-2014, found that gross domestic product is not a significant factor. Bílková (2020) states that in the OECD countries of which Hungary, Poland, the Czech Republic and the Slovak Republic are members, gross domestic product is significantly affected not only by the minimum wage but also by the average wage. Another factor affecting the average wage is also unemployment. On the contrary, the inflation rate does not have a statistically significant effect on the average wage. Generally, the V4 countries in comparison with West European Economics are relatively low at the level of the average wage. The direct dependence between gross domestic product growth and wages in Slovakia was confirmed by the results of the Morvay (2015). This positive effect was already expected according to the Sujanová and Sujan (2002), which among other things, modelled the expected development of wages, GDP or price levels.

Many studies have examined the relationship between minimum wage and unemployment. In general, the conclusions of these studies can be divided into two groups - the first group of studies where the increase in the minimum wage led to a reduction of unemployment and the second group of studies, where, on the contrary, the results confirmed the negative effect of the minimum wage on employment. In the Czech Republic, in some years, compared to other V4 countries, there was a particular situation in the fact that the minimum wage did not increase. For this reason, Picl (2018) states that the minimum wage does not have a significant impact on the unemployment rate in the Czech Republic. Pavelka et al. (2014) studied selected aspects of the minimum wage in the Czech Republic between 1991 and 2012 in the context of unemployment and living minimum found out that in Poland there is no significant dependence between wage and unemployment. The results point to an ambiguous relation between unemployment and the minimum wage because of a different political orientation when the leftwing governments valorised the minimum wage more often than right-wing governments.

According to the analysis of Kaderábková and Jasová (2016) it was found out that the rise of the minimum wage was followed by unemployment growth in all V4 countries except of the Slovak Republic. Similar results about the negative impact of growth minimum wage on employment were verified by the results of studies in the V4 countries. In the Czech Republic and the Slovak Republic by Fialová and Myslíková (2009), in Poland Fatula (2018), Broecke et al. (2017). Fatula (2018) also mentions that the minimum or average wage has an impact on tax and levy burden of wages. A similar negative impact of an increase in the minimum wage on employment indicates studies that were done in V4 (Aaronson \& French, 2007). Studies carried out by Cengiz et al. (2019) state that increasing minimum wages do not affect employment negatively. An important factor is that these studies were not done in the V4 countries. Apart from minimum wage, average wage could be another factor which could have a negative effect on employment in Poland (Majchrowska \& Zółkiewski, 2012). The positive impact of growths is increase in minimum wage and employment rate in Poland by Nedomlelová et al. (2017). Lindner and Reizer (2020) analysed these aspects in Hungary and found out that the growth of wage also has a positive effect on employment, which was on the other hand not confirmed by Pauhofová and Stehlíková (2018).

For employees, the important thing is the net wage. Whether the employer pays the employee wages only at the minimum wage level or even higher, the total personnel costs, i.e. the gross wage and related levies to social security contributions, are important to him. The high tax and burden of charges create pressures to decrease wages, as companies aim not only to optimize wage costs. The basic function of these tax levies is to ensure the redistribution of taxpayers' incomes. Personal income tax, which represents a tax levy on an employee's gross wage, is progressive, causing the fact that with the income increase the tax burden grows faster than the taxpayer's own income (Dardanoni \& Lambert, 2002). Labour tax burden influences labour markets. Čermáková et al. (2016) analysed the influence of tax burden on labour markets in the V4 countries. The negative influence of tax burden on labour markets was found out in the Czech Republic, in the Slovak Republic and Hungary. This influence was the lowest in Poland.

As part of business activities, the entrepreneur takes into account not only 
aspects of direct or indirect taxes (Konečná \& Andrejovská, 2020). Moreover, a significant component of personal costs are the social security contributions usually including social security payments and health insurance. Social security contributions significantly affect the unemployment rate, as the conclusion of research by Cristea and Zeti (2019) is that in European countries, there is a positive correlation between total social security contributions and the unemployment rate. The problem of high labour tax burden is in EU countries which joined the European Union after the year 2000. Among these countries were also V4 countries. The high labour tax burden has negatively affected employment and this has reduced the level of minimum and average wage (Fialová \& Schneider, 2009). If these payments are high, employers tend to shift at least part of these levies to employees in the form of lower wages. The high tax and burden of charges also negatively affect the competitiveness of companies and influence their financial performance, which could also influence negatively, unemployment or wages. In addition to the tax burden, a change in the price level is also a factor influencing wages there is a positive dependence between wages and inflation in the countries analysed in this study.

The economic condition and competitiveness of countries of the Visegrad Group are linked by significant factors from economic areas, but each country faces different economic problems, which determines their economic status and position in the world. The pressure of economies on sustainable economic development, the strategy and principles of monitoring and managing macroeconomic indicators have affected their diverse economic outcomes. The economic situation of Slovakia, the Czech Republic, Poland and Hungary is more than similar and the countries achieve the same results, in terms of either their economic performance or competitiveness (Bacik et al., 2019).

As is apparent from the overview of research studies, the comprehensive analysis assessing the impact of all indicators, i.e. the implicit tax rate on labour, unemployment rate, gross domestic product and the consumer price index on the minimum or average wage has not yet been implemented in this field. This implies the uniqueness and high added value of this study. Another unique feature of the article is the performance of such an analysis in multiple states at the same time, which also enables to make a comparison of the results found.

\section{Data}

The main objective of this study is to evaluate minimum and average wages in relation to selected macroeconomic indicators that may have a direct impact on the development of minimum and average wages of the examined countries - the Czech Republic, Slovakia, Poland and Hungary. Conclusions on the nature of the minimum and average wages of the countries examined are drawn from the results of empirical analyses and did not give completely clear results. The evaluation of the selected identifiers of this study is based on the validation process of the following working hypotheses:

H1: Macroeconomic indicators and their development influence decisions on the amount of the minimum wage.

H2: The average wage is adapting to the development of minimum wages and macroeconomic indicators.

The variable unemployment rate, gross domestic product, implicit price deflator and implicit tax rate on labour are considered macroeconomic indicators.

Concerning the availability of data, the period of 13 years, 2005-2017, is analysed. The reason is the availability of the values of the implicit tax rate on labour that has been publicly available only since 2005 . For the year 2018 , the implicit tax rate is not yet known. The inclusion of older data is not useful because the countries examined have gradually introduced a fixed increase in the minimum wage. The exclusion of older data is motivated by the fact that they have a much lower level of impact on the future development of the minimum wage.

Data for the study are obtained from the Eurostat database (Eurostat, 2020), the Organisation for Economic Cooperation and Development (OECD, 2020) and from the databases of national statistical offices (Czech Statistical Office, 2020; Statistical Office of the Slovak Republic, 2020; Statistics Poland, 2020; Hungarian Central Statistical Office, 2020).

The economic model of the minimum wage is formulated as follows (1), the expected effect of exogenous variables on the endogenous variable according to (2): 


$$
\begin{aligned}
& M W_{t}=f\left(A W_{t}, U_{t}, G D P_{t}, C P I_{t}, I T R_{L}\right), \\
& M W_{t}=f(+,-,+,+,-),
\end{aligned}
$$

the economic model of the average wage is formulated as follows (3), the expected effect of exogenous variables on the endogenous variable according to (4):

$$
\begin{aligned}
& A W_{t}=f\left(A W_{t}, U_{t}, G D P_{t}, C P I_{t}, I T R_{L}\right), \\
& A W_{t}=f(+,-,+,+,-),
\end{aligned}
$$

where $M W_{t}$ is the minimum wage [in national currency], $A W_{t}$ is the average wage [in national currency], $U_{t}$ unemployment rate [in \%], $G D P_{t}$ is a gross domestic product [in national currency], $C P I_{t}$ is the consumer price index [in \%] and $I T R_{L}$ is the implicit tax rate on labour [in \%].

The data are on an annual basis, in national currency units and at current prices. For the analysis, the indicators are gradually adjusted using a logarithmic difference. Selected exogenous variables allow estimating more accurately the effects on the development of endogenous variables of the countries examined. The abstract of the study does not compare regional differences in the V4 countries.

To determine the number and selection of variables, the links between variables that are closely related were considered. In practice they cannot be separated, as well as the conclusions of empirical studies and theories. The indicator of the minimum wage is chosen, because in almost all developed countries of the world it is possible to find the use of the threshold limiting wages in the economy from below, which can take many forms. The statutory minimum wage can pursue a number of goals and functions: from reducing poverty and wage inequality, through improving the motivation of low-income groups to work, to putting pressure on companies to increase productivity. The study does not capture all the effects of the minimum wage, such as the dismissal of unproductive employees or the motivation of people to take up employment. The importance of the minimum wage is mostly argued in the social field. Above all, the minimum wage increases the purchasing power of low-income families, which is another reason to examine the dependence of the values of the minimum wage on selected macroeconomic indicators. In addition to the amount of gross wages, information on the tax burden on labour is important for both employees and employers.

There was selected the labour tax burden indicator that is best reflected by the $I T R_{L}$ implicit rate on labour tax defined by (5),

$$
I T R_{L}=\frac{\text { tax on wages }}{\text { wages costs }},
$$

that, unlike the nominal rate or the effective rate, not only monitors the burden of the personal income tax but also considers social insurance that is carried by both the employee's and the employer's party. For more about implicit tax rates see, e.g., Onaran et al. (2012). The advantage of using $I T R_{L}$ from the effective rate indicator is mainly the fact that $I T R_{L}$ takes into account not only social insurance paid by the employee, but also by the employer and compares it to the total personal costs that the employer has in the accounts in labour costs (Mendoza et al., 1994). By increasing the minimum wages of employees, the costs of wages, which, e.g., are reflected in the prices of products and services in relation to the consumer price index, are also increasing. In general, the consumer price index represents the consumer habits of the average citizen. It is used to determine the rise in living costs and as a benchmark for trade unions for negotiating the salaries increase. Monitoring average wages indirectly strengthens social cohesion in society. Another important factor is the protection of workers in sectors without a trade union, whose bargaining power with employers is very weak.

Adjusted time series without seasonal variables are used for analysis. In accordance with economic theory, all series are logarithmically transformed. Logarithmically transformed time series are marked with italic letters $m w, a w, u$, $g d p, c p i$, $i r_{l}$. The development of seasonally adjusted time series $m w$ and $a w$ of the countries examined is shown in Fig. 1.

Fig. 1 shows the development trend of the minimum and average wage. Gradual growth of both indicators is evident in all V4 countries. Institutional differences are constant, there are not inequalities and therefore a differentiated effect of the minimum and average wage in selected countries cannot be expected. The jump can be observed on the basis of declining GDP and high unemployment, when people are not motivated to look for and accept work in Poland (Strateg, 2020). This phenomenon is further exacerbated by the high rate of "labour" emigration of Poles abroad. The polish 


\section{Fig. 1: Development of the minimal and average wage in analysed states}

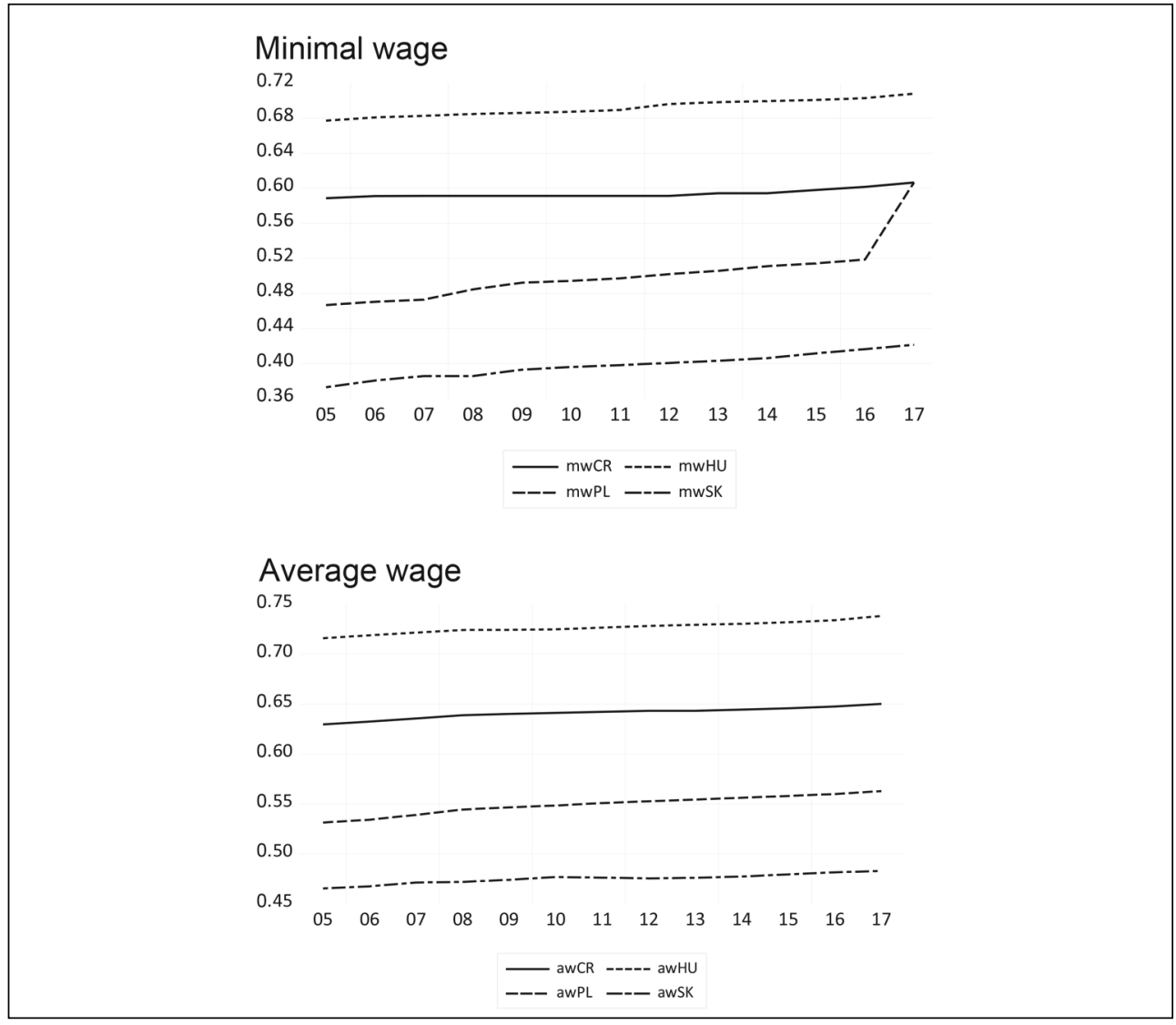

Source: EViews 10

migrants provide evidence that they respond to differences in the labour markets (Rosso, 2020). The minimum wage is the lowest in Slovakia due to the policies adopted by the government. The minimum wage can be expected to increase in all V4 countries, although the negative economic effects on the growth of financial demands may deepen unemployment in direct relation to the rising minimum wage. The influence of a wide range of socio-economics and companyrelated factors has decreased the low earnings (Ryckowski \& Maksim, 2018). The rising average wage seems to be more fundamental, which would suppress the negative effects of the development of the minimum wage and the low earnings. The amount of the minimum wage is determined by the law or regulation and is significantly influenced by the institutional environment (Tvrdoň, 2018). The institutional environment significantly influences the labour market, not only by determining the amount of the minimum wage, but also, for example, by the tax and contribution burden on wages. However, the government's decision to set the minimum wage depends not only on the tax burden, but also on the phase of the economic cycle, unemployment or price stability (Calmfors, 1995). This is also the reason for the inclusion of selected variables in the economic model (1) and (3). All these aspects must be taken into account by national governments when setting the minimum wage.

The subject of the analysis of economic models (1), (2), (3), (4) are seasonally adjusted 
data using econometric software EViews and Microsoft Excel. In order to obtain a model in accordance with economic theory examining the interrelationships between variables, the correlation analysis, VAR model construction, impulse-response analysis and Granger causality testing are used for work with the data. The methodological apparatus uses methods of empirical and logical and deductiveinductive approaches. To determine the order of integration of the time series aw, $m w, u, g d p, c p i$, itr, of the countries examined, i.e. whether the time series is stationary or non-stationary, unit root tests of the Augmented Dickey-Fuller test (ADF) and Phillips-Perron test (PP) are used. For more details see, e.g., Levendis (2019). The methodological procedure of the study corresponds to the scope and construction of models of multivariate stationary time series.

\section{Results}

Due to the extensiveness of the data, the study does not list statistically insignificant variables or statistically significant explained variables that are not subject to the study.

\subsection{Correlations}

Tab. 1 displays the values of Pearson's correlation coefficients examining the strength of dependence between the selected pair of indicators.

Data for the Czech Republic, Slovakia, Poland and Hungary show a positive relation and interdependence between minimum wage indicators, average wage, gross domestic product and consumer price index. There is a negative relation between the minimum and the average wage and unemployment, where unemployment is falling as wages rise. Weak linear dependence up to almost no dependence is marked in the Czech Republic and Poland between the minimum wage and $I T R_{L}$, for Poland also for the average wage indicator.

\subsection{Analysis of Integration}

The length of the delay was tested based on the Akaike information criterion (AIC) and Schwarz information criterion (SBC). Both criteria provided very different results within the countries examined. The delay of 1 period for the Czech Republic confirms the condition that the minimum wage is determined on the basis of all known facts and is not predicted. The delay of 0 periods for Slovakia, Poland and Hungary confirms the development of the minimum wage, which is planned in these countries for up to several years. The length of delay used in the models is estimated on the basis of knowledge of the actual relations of the variables analysed and therefore corresponds in the best way to the real market situation. One period is selected as the most appropriate delay. This discrepancy prevents possible differentiation of series at the same level and better interpretation of the results in the observed period.

Tab. 2 provides an overview of the critical values of ADF and PP tests for the selected variables. Both tests identified the stationarity only after the transition to the series of other differences, i.e. that time series are integrated into order 2 code I(2) at a significance level of $1 \%$. The order of integration has been examined for time series with a delay of one period.

\subsection{Estimation and Diagnostics of the VAR Model}

The VAR model used to estimate parameters is a verification of the stability of the formula system. According to Levendis (2019), the

Tab. 1: Correlation coefficients of analysed countries

\begin{tabular}{l|c|r|r|r|r|r|r|r}
\multirow{2}{*}{ Variable } & \multicolumn{2}{|c|}{ Czech Republic } & \multicolumn{2}{c|}{ Slovakia } & \multicolumn{2}{c|}{ Poland } & \multicolumn{2}{c}{ Hungary } \\
\cline { 2 - 9 } & $\boldsymbol{m w}$ & $\boldsymbol{a w}$ & $\boldsymbol{m w}$ & $\boldsymbol{a w}$ & $\boldsymbol{m w}$ & $\boldsymbol{a w}$ & $\boldsymbol{m} \boldsymbol{w}$ & \multicolumn{1}{c}{$\boldsymbol{a w}$} \\
\hline$m w$ & 1.0000 & 0.8220 & 1.0000 & 0.9709 & 1.0000 & 0.5893 & 1.0000 & 0.9817 \\
\hline aw & 0.8220 & 1.0000 & 0.9709 & 1.0000 & 0.5893 & 1.0000 & 0.9817 & 1.0000 \\
\hline$u$ & -0.8139 & -0.6357 & -0.5666 & -0.5679 & -0.4925 & -0.7784 & -0.4239 & -0.4168 \\
\hline$g d p$ & 0.9074 & 0.9628 & 0.9132 & 0.9540 & 0.5674 & 0.9974 & 0.8478 & 0.9028 \\
\hline$c p i$ & 0.7156 & 0.9724 & 0.8961 & 0.8877 & 0.4188 & 0.9517 & 0.9416 & 0.9454 \\
\hline$i t r_{i}$ & 0.0178 & -0.4499 & 0.8003 & 0.7212 & 0.1525 & 0.0925 & 0.3149 & 0.3644 \\
\hline
\end{tabular}




\section{Tab. 2: ADF and PP test of analysed countries}

\begin{tabular}{|c|c|c|c|c|c|c|c|c|}
\hline \multirow{3}{*}{ Variable } & \multicolumn{8}{|c|}{$2^{\text {nd }}$ difference } \\
\hline & \multicolumn{2}{|c|}{ Czech Republic } & \multicolumn{2}{|c|}{ Slovakia } & \multicolumn{2}{|c|}{ Poland } & \multicolumn{2}{|c|}{ Hungary } \\
\hline & ADF & PP & ADF & PP & ADF & PP & ADF & PP \\
\hline$m w$ & $-6.11^{* * *}$ & $-6.38^{* * *}$ & $-3.35^{\star *}$ & $-5.21^{\star * *}$ & -0.13 & -0.126 & $-3.29^{* *}$ & $-4.20^{* * *}$ \\
\hline aw & $-2.93^{\star *}$ & $-2.92^{\star *}$ & $-4.95^{\star \star \star}$ & $-7.37^{\star \star \star}$ & -0.21 & $-3.35^{\star \star \star}$ & -1.89 & -1.64 \\
\hline$u$ & $-3.50^{* * \star}$ & $-4.02^{* * *}$ & $-5.93^{* * *}$ & $-3.10^{* *}$ & $-3.85^{\star * *}$ & -2.518 & $-4.10^{* * *}$ & $-4.20^{* *}$ \\
\hline$g d p$ & $-2.99^{* *}$ & $-2.82^{*}$ & $-3.27^{* *}$ & $-4.33^{* * *}$ & $-5.13^{* * *}$ & $-7.06^{* * *}$ & $-4.20^{* * *}$ & $-6.00^{* *}$ \\
\hline$c p i$ & $-3.97^{\star \star \star}$ & $-7.15^{\star \star *}$ & $-2.69^{*}$ & $-5.59^{\star \star \star}$ & -2.14 & -1.09 & -2.50 & -2.50 \\
\hline$i t r_{1}$ & $-6.11^{* * *}$ & $-5.70^{* * *}$ & $-5.07^{* * *}$ & $-9.43^{* * *}$ & $-4.82^{* * *}$ & $-16.33^{* * *}$ & $-3.72^{* * *}$ & $-3.54^{* *}$ \\
\hline
\end{tabular}

Source: own according to EViews 10

Note: ${ }^{* * *},{ }^{* *},{ }^{*}$ indicate the significance level of $1 \%, 5 \%, 10 \%$.

estimated VAR model is considered stable (stationary) if the actual numbers are lower than 1. The eigenvalues of $m w$ and aw matrix for the VAR model are lower than 1, which confirms the stability of the estimated model.

The output of the VAR model is a combination of dependent variables and independent variables. The results of the VAR model in Tab. 3 for the Czech Republic and Poland confirm that it is not important to pay attention to the influence of macroeconomic variables on the minimum wage. Almost no statistically significant macroeconomic indicator is confirmed. Results of the analysis do not confirm the results in Poland of the study by Nedomlelová et al. (2017) or Kadeřábková and Jasová (2016) in the Czech Republic. The minimum wage formula for Slovakia and Hungary illustrates that $I T R_{L}$ alone has a statistically significant impact on the minimum wage.

The above-mentioned finding, compared to the formula of the economic model for Slovakia, implies that $I T R_{L}$ has a statistically significant positive effect on the development of the minimum wage. If the $I T R_{L}$ increases by $1 \%$, the minimum wage will increase by EUR 0.5109 . For Hungary, $I T R_{L}$ is also statistically significant variable that, on the contrary, negatively affects the minimum wage at $5 \%$ of the significance level. If the $I T R_{L}$ increases by $1 \%$, the minimum wage will decrease by HUF 1.5623. It has been confirmed that companies and workers may agree to report less than the true amount of earnings to the fiscal authorities (Tonin, 2011). Other economic variables appear to be insignificant. It is obvious that the variables do not have a statistically significant

\section{Tab. 3: VAR model for minimal wages}

\begin{tabular}{|c|c|c|}
\hline State & VAR model & \\
\hline Czech Republic & $\begin{array}{l}m w_{t}=1.4497^{\star \star \star} m w_{t}(-1)-0.1073 a w_{t}(-1)-0.0010 u_{t}(-1)-0.4595 g d p_{t} \\
(-1)+0.2476 c p i_{t}(-1)+0.1155 \operatorname{itrl}_{t}(-1)+0.0837\end{array}$ & (6) \\
\hline Slovak Republic & $\begin{array}{l}m w_{t}=-0.1911 m w_{t}(-1)+2.5159 a w_{t}(-1)-0.2222 u_{t}(-1)-0.8413 g d p_{t} \\
(-1)+2.4068 c p i_{t}(-1)+\mathbf{0 . 5 1 0 9 * *} \operatorname{itrl}_{t}(-1)-13.5828\end{array}$ & (7) \\
\hline Poland & $\begin{array}{l}m w_{t}=6.6805 m w_{t}(-1)-18.9308 a_{t}(-1)-0.2824 u_{t}(-1)+21.5995 g d p_{t} \\
(-1)-5.7542 \mathrm{cpi}_{t}(-1)-0.7497 \text { itrl }_{t}(-1)-5.3920\end{array}$ & (8) \\
\hline Hungary & $\begin{array}{l}m w_{t}=0.5070 m w_{t}(-1)+0.6088 a_{t}(-1)-0.1112 u_{t}(-1)+0.4519 g d p_{t} \\
(-1)+0.1354 c p i_{t}(-1)-1.5623^{* *} i t r l_{t}(-1)-1.7452\end{array}$ & (9) \\
\hline
\end{tabular}

Note: ${ }^{* * *},{ }^{* *},{ }^{*}$ indicate the significance level of $1 \%, 5 \%, 10 \%$. 
effect on the growth of the minimum wage in the V4 countries. It can be stated that people remain poor regardless of the economic cycle on the basis of the indicator of unemployment, GDP and the average wage. It also follows that setting a minimum wage is more of a political issue in the countries analysed.

The results of the VAR model according to Tab. 4 showed that it is statistically more significant to pay attention to the average wage. Its development is not random, it is dependent on macroeconomic indicators. In the formula, macroeconomic variables act as statistically significant at the significance level of $1 \%{ }^{* * *}$, $5 \%$ ** and $10 \%$ *.

In the case of the VAR model formula it is apparent for the Czech Republic that with an increase in the average wage by $1 \%$ one year ago, under the conditions of ceteris paribus, the current value of the average wage will increase by $0.9086 \%$. The minimum wage, the consumer price index, the $I T R_{L}$ and unemployment have a statistically significant impact on the average wage. They are statistically significant at a significance level of $1 \%$. The impact of these variables on volatility is too small. In the case of unemployment and $I T R_{L}$, there is a significant effect of the minimum wage, about half as high, affecting the average wage. It can be said that increasing the share of the minimum wage in the average wage will increase unemployment. This result is different from the analysis between wages and unemployment in the Czech Republic performed by Pavelka et al. (2014) or Pauhofová and Stehlíková (2018) in the Slovak Republic, who state that there is not clear relationship between unemployment and wage.

The VAR model from the data for the Slovak Republic confirms the statistically significant impact of the minimum wage on the average wage, since, as the formula shows, by increasing the minimum wage by EUR 1.0, the average wage will increase by EUR 1.1659. A significant variable of the model is also a gross domestic product.

The consumer price index has a statistically significant impact on the average wage in Poland. If inflation increase by $1 \%$, the average wage will decrease by PLN 0.8842 . Low labour costs are one of the factors that enable Poland to increase its participation in international trade and, moreover, low wages attract investments in low-technology industries. In accordance with the same result of the Slovak Republic, the average wage is affected by the growth of the gross domestic product. The positive development of GDP in Poland and Slovakia has an impact on the growth of the average wage, when lower to negligible unemployment can be expected Bílková (2020).

$I T R_{L}$ has a statistically significant impact on Hungary's average wage. An increase of $I T R_{L}$ by $1 \%$ will reduce the average wage by HUF 0.7878 . The increase in the average wage compared to the previous year is $1.2328 \%$ higher and this growth is influenced by the decline in unemployment. It can be said that the growth of the average wage and the decrease of the $I T R_{L}$ is caused by the faster growth of average wages than the minimum wages, Fig. 1.

There is a discrepancy in the case of defined assumptions regarding unemployment, where the average wage was expected to increase when unemployment decreased for the countries of the Czech Republic, Slovakia and Poland. Another contradiction arises with $I T R_{L}$ of countries of the Czech Republic and

\section{Tab. 4: VAR model for average wages}

\begin{tabular}{|c|c|c|}
\hline State & VAR model & \\
\hline Czech Republic & 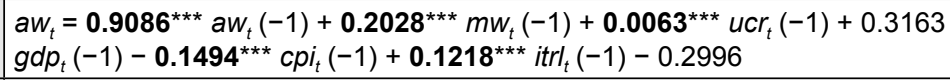 & $(10)$ \\
\hline Slovak Republic & $\begin{array}{l}a w_{t}=-1.8653 \mathrm{aw}_{t}(-1)+\mathbf{1 . 1 6 5 9 *} \mathrm{mw}_{t}(-1)+0.0796 u_{t}(-1)+\mathbf{0 . 6 1 4 4}^{\star *} g d p_{t} \\
(-1)-1.8340 \mathrm{cpi}_{t}(-1)+0.1125 \mathrm{itrl}_{t}(-1)+6.050\end{array}$ & $(11)$ \\
\hline Poland & $\begin{array}{l}a w_{t}=1.2247 a w_{t}(-1)-0.1563 m_{w}(-1)+0.0268 u_{t}(-1)+1.2665^{\star *} g d p_{t} \\
(-1)-\mathbf{0 . 8 8 4 2}^{*} \text { cpi }_{t}(-1)-0.0071 \text { itrl }_{t}(-1)-0.7772\end{array}$ & $(12)$ \\
\hline Hungary & $\begin{array}{l}a w_{t}=1.2328^{\star *} a w_{t}(-1)-0.0194 m w_{t}(-1)-0.1026 u_{t}(-1)+0.1252 g d p_{t} \\
(-1)-0.2026 \text { cpi }_{t}(-1)-0.7878^{\star *} \text { itrl }_{t}(-1)+0.1337\end{array}$ & $(13)$ \\
\hline
\end{tabular}




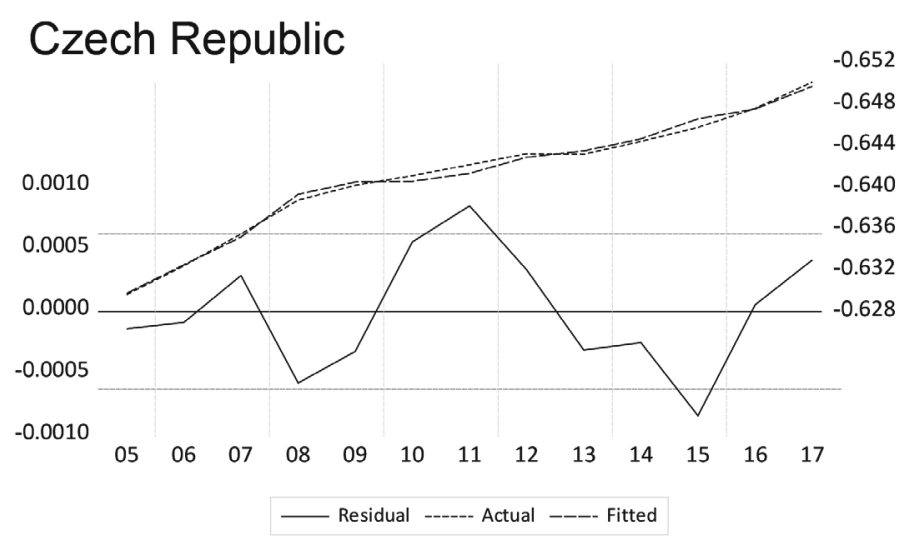

\section{Slovak Republic}

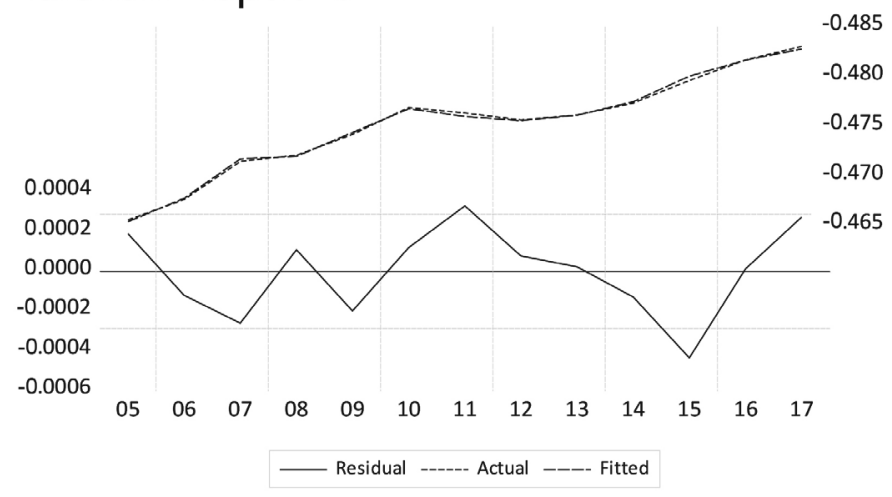

\section{Poland}

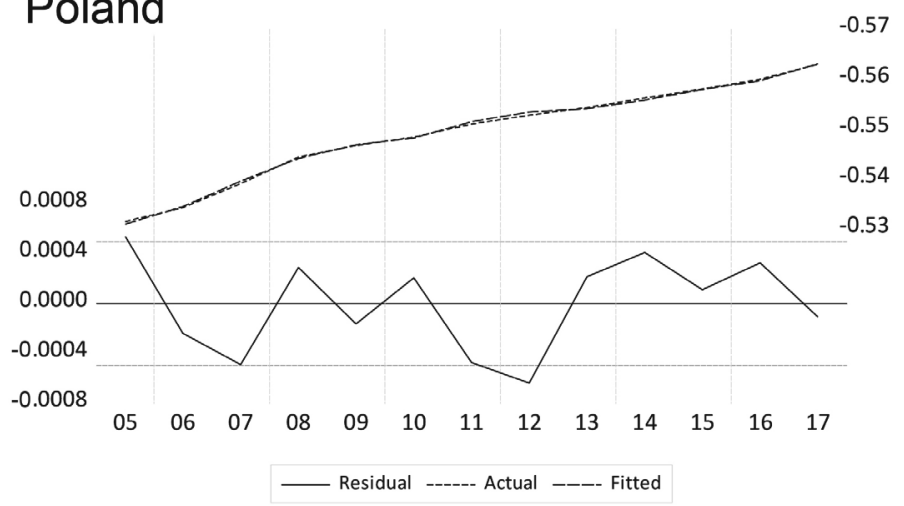




\section{Fig. 2: Actual and balanced values of average wage - Part 2}

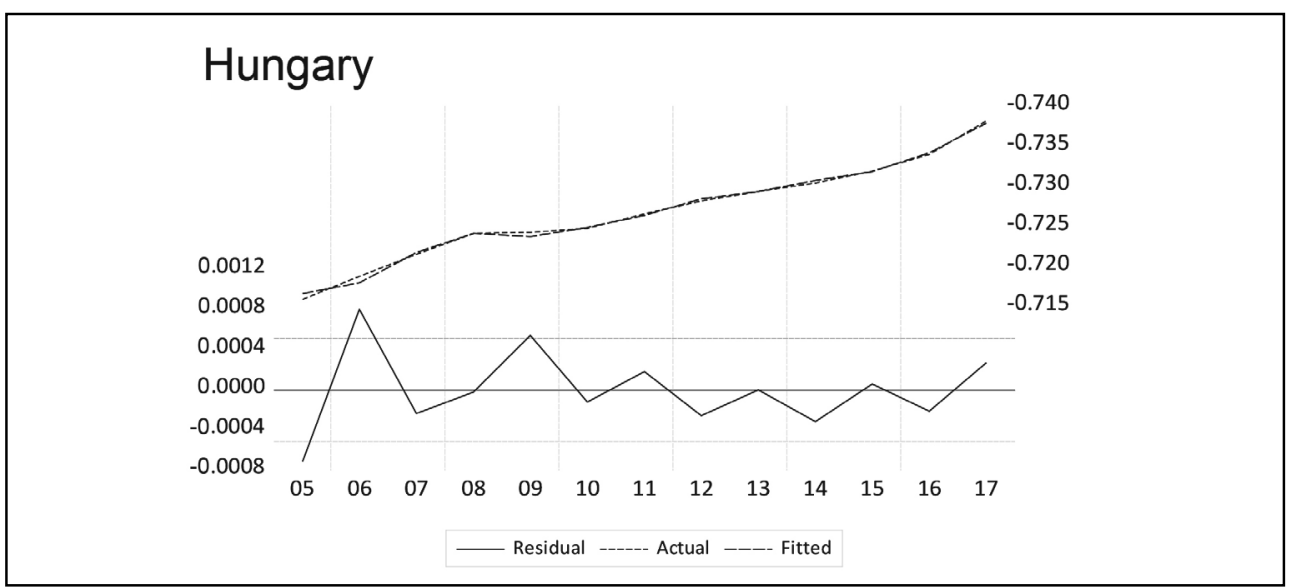

Source: EViews 10

Slovakia. When $I T R_{L}$ increases, the average wage decreases. This is confirmed by the $R^{2}$ determination coefficient of the aw formula that indicates that approximately $99.88 \%$ of the average variability can be clarified in the Czech Republic. A similar explanation applies to Slovakia $(97.19 \%)$, Poland $(99.66 \%)$ and Hungary $(99.12 \%)$. The other parameters match the specified parameters of the theoretical model (2) and (4). According to the results of formulas (10), (11), (12), (13), significant effects on the development of the average wage can be expected even if the values that affect the defined average wage assumptions are not high. The clarity of the effect of macroeconomic indicators on changes in the average wage, expressed by the adjusted $R^{2}$ coefficient, is high in the Czech Republic $\mathrm{R}^{2}=99.74 \%$, Slovakia $R^{2 b}=93.83 \%$, Poland $R^{2}=97.65 \%$ and Hungary $R^{2}=98.07 \%$, and the adjacency of the reality model is confirmed. The degree of accordance of the actual development of the average wage with model-calculated values including variances (residual) is shown in Fig. 2. The explanatory capabilities of the variables can be significantly higher, but the results are sensitive to the chosen delay, which can reduce the explanatory capability of the model.

The Durbin-Watson test is used to test autocorrelation. The resulting values of the Durbin-Watson statistics test criterion (DW) for the Czech Republic DW $=1.3821$, Slovakia

\section{Tab. 5: Czech Republic, Granger Cause test}

\begin{tabular}{|c|c|}
\hline Variables & P-value \\
\hline$m w$ does not Granger Cause aw & $0.0001^{* * *}$ \\
\hline$m w$ does not Granger Cause $g d p$ & $0.0034^{* * *}$ \\
\hline$m w$ does not Granger Cause $u$ & $0.0100^{* * *}$ \\
\hline aw does not Granger Cause cpi & $0.0648^{*}$ \\
\hline gdp does not Granger Cause aw & $0.0028^{* * *}$ \\
\hline itr, does not Granger Cause aw & $0.0034^{* * *}$ \\
\hline$u$ does not Granger Cause aw & $0.0362^{* *}$ \\
\hline
\end{tabular}




\begin{tabular}{|c|c|}
\hline Variables & P-value \\
\hline$m w$ does not Granger Cause aw & $0.0591^{*}$ \\
\hline$m w$ does not Granger Cause $g d p$ & $0.0786^{*}$ \\
\hline$i t r_{1}$ does not Granger Cause $m w$ & $0.0067^{* * *}$ \\
\hline$m w$ does not Granger Cause itr & $0.0054^{* * *}$ \\
\hline aw does not Granger Cause itr & $0.0386^{* *}$ \\
\hline cpi does not Granger Cause itr, & $0.0047^{* * *}$ \\
\hline gdp does not Granger Cause itr, & $0.0284^{* * *}$ \\
\hline
\end{tabular}

Note: ${ }^{* * *},{ }^{* *},{ }^{*}$ indicate the significance level of $1 \%, 5 \%, 10 \%$

$D W=1.6268$, Poland DW $=1.8619$ and Hungary $\mathrm{DW}=2.7594$. The compared values with the tabular value indicate a statistically insignificant negative autocorrelation. We do not reject the null hypothesis based on the assumption that there is no autocorrelation between the indicators at the significance level of $5 \%$.

\subsection{Granger Causality Test}

An important part of the analysis of time series is the examination of the causality between different blocks of modelled variables. The Granger causality test (Levendis, 2019) is applied for that purpose.

The existence of causal dependencies according to Granger in the aw, $m w, u, g d p, c p i$ and itr, time series of examined countries are listed in Tabs. 5, 6, 7, 8. As the test results in the tables show, we can confirm that there are dependencies between mentioned variables since the resulting $p$-values are statistically significant at the significance level of $1 \%, 5 \%$, $10 \%$. Other dependencies based on the resulting p-value are not significant on significance levels, we do not reject $H 1$ in favour of $H 2$.

For all countries examined, the predominantly one-sided causal relation in the development of minimum wages, unemployment and gross domestic product are confirmed, which are similar the results of the study by Bílková (2020). Gross domestic product is usually presented as a universal and most popular measure of economic development, which does not include social differences in relation to the achieved income level. The turnover of the unemployed is confirmed, which represents a negative movement in the labour market, such as redundancies or dismissal of those who cannot find work in the long term. In particular, volatility in the turnover of the unemployed has an impact on the labour market in relation to regular increases in the minimum wage. This is an intervention in a market mechanism, the costs of which are mainly borne by employers. They are more sensitive to fluctuations of the market mechanism, react negatively to it, and transfer their uncertainty to both economic and social indicators, which may be one of the reasons for increasing unemployment in the country. In general, it is assumed that employees with lower wages change jobs more or become unemployable over time. Similar conclusions about the existence of a positive dependence between GDP and wage growth in

\section{Tab. 7: Poland, Granger Cause test}

\begin{tabular}{l|l}
\multicolumn{1}{c|}{ Variables } & P-value \\
\hline cpi does not Granger Cause $m w$ & $0.0374^{* *}$ \\
\hline$c p i$ does not Granger Cause $g d p$ & $0.0664^{*}$ \\
\hline
\end{tabular}


Tab. 8: Hungary, Granger Cause test

\begin{tabular}{l|l}
\multicolumn{1}{c|}{ Variables } & \multicolumn{1}{c}{ P-value } \\
\hline$m w$ does not Granger Cause $u$ & $0.0029^{* \star *}$ \\
\hline cpi does not Granger Cause aw & $0.0993^{*}$ \\
\hline$u$ does not Granger Cause aw & $0.0136^{* *}$ \\
\hline aw does not Granger Cause $u$ & $0.0168^{* *}$ \\
\hline cpi does not Granger Cause $u$ & $0.0111^{\star *}$ \\
\hline
\end{tabular}

Source: own according to EViews 10

Note: ${ }^{* \star *},{ }^{* *},{ }^{*}$ indicate the significance level of $1 \%, 5 \%, 10 \%$.

Slovakia were found by Morvay (2015). On the contrary, Balcar and Gottwald's (2016) analysis of the relationship between wage growth and GDP was not confirmed. However, it should be noted that the reason may be the fact that this analysis was focused on the time to the period when the recession was taking place in the Czech Republic.

As the results of the tests in the Czech Republic show, there is a unilateral causal dependency within the meaning of Granger causality for the minimum wage, which influences with delay an average wage, gross domestic product and unemployment. In this case, there is agreement with the results of Pernica and Janáč (2015). The consumer price index is affecting the average wage with delay. The development of the average wage is influenced by the development of the gross domestic product, $I T R_{L}$ and unemployment. The existence of the relationship is confirmed by the indicators of unemployment, $I T R_{L}$ and average wages, formula (10), although the influence of the variables is the opposite, formula (4). If the minimum wage is not set close to the average wage, people will be motivated to find work and do work, unemployment will fall. As a result, household consumption will grow, the company will grow richer, which will result in an in gross domestic product increased growth as an indicator of growth in investment and consumption.

The results of the tests in Slovakia in Tab. 6 show that there is a unilateral causal dependence of the minimum wage within the meaning of Granger causality on the average wage and gross domestic product and $I T R_{L}$. $I T R_{L}$ 's development is influenced by the development of average wage, gross domestic product and the consumer price index. These conclusions are consistent with the study by
Pernica and Janáč (2015). Morvay (2015) also mentions that with wage growth, gross domestic product grows, which are also confirmed by the results of this analysis. In the case of the development of the average wage, the average value of the European Union is approaching not only in Slovakia but also in other analysed V4 countries, which is also reflected in the increase of the tax burden due to the still valid sliding progressive tax rate (Bajus et al., 2015).

Based on the values in Tab. 7, which captures the results for Poland, there is a unilateral causal dependence of the consumer price index, which is capable of affecting the minimum wage and gross domestic product with delay.

As the test results for Hungary in Tab. 8 show, there is a double-sided dependence of average wage and unemployment, and a onesided dependency, where unemployment is influenced by the development of the minimum wage, average wage and the consumer price index. With higher unemployment, a negative effect on the average wage and its differentiation in the country can be expected. Similar results are reported in the Delteil et al.'s study (2004).

The use of the Granger causality test seems appropriate on the basis of the minimum wage test performed. Most economic variables are significant for explaining the minimum wage, but they work differently in the V4 countries. Given the institutional conditions of the V4 countries, it can be assumed that these are homogeneous areas, Fig. 1, in terms of the development of the average wage depending on various factors. It can be said that the rising minimum wage in terms of the share of the average wage in the V4 countries is statistically significantly influenced by macroeconomic indicators. 


\section{Discussion}

The study cannot be considered as the final number of existing time series models of minimum and average wage. Created economic models contained variables that reflect the findings of researchers and empirical studies and literature at the time this study was being carried out. The current influence of macroeconomic variables is outlined in six hypotheses. A difficult part of the study was, above all, verifying the validity of the claim of the economic model of the minimum wage (1).

Three transformations were used in the work. First, logarithmic values were calculated from the data obtained and subsequently the transformation of the first and second series was carried out. All used variables appear in their second differences. Individual variables were considered time-delayed by one period.

H1: Macroeconomic indicators and their development influence decisions on the amount of the minimum wage.

Based on the results of the estimated models, it can be clearly stated that in the estimated formula (6), (7), (8), (9) of the minimum wages of the VAR model the average wage does not affect the minimum wage. Therefore, this conclusion of the analysis does not agree with the above study results. On the contrary, they agree with the conclusions of Picl (2018), which states that the minimum wage does not affect unemployment. Also, the conclusions of Fatula (2018) are not identical with the conclusions of this study, if the minimum wage in any of the V4 countries is considered a dependent variable. In Slovakia and Hungary, the dependence of the minimum wage on $I T R_{L}$ was found. The positive impact of $I T R_{L}$ on the minimum wage in the case of Slovakia, formula (7) does not agree with the conclusion of Fialová and Schenider (2009), who on the contrary state that the high tax burden reduces the minimum wage, which was found in this study in Hungary, formula (9).

It is not possible to draw a general clear conclusion and predict the impact on the minimum wage based on an increase in the average wage. The development of the minimum wage in the countries examined mainly reflects the development of a politically oriented government in the country, which is confirmed by the development of the minimum wage of the countries examined (Fig. 1; Statistical Office of the Slovak Republic, 2020; Statistics Poland, 2018; Hungarian Central Statistical
Office, 2020). When raising the minimum wage, it is necessary to respect the fact that if it is closer to the average net wage established upon market principles, this fact has a negative effect on macroeconomic indicators such as unemployment. There is evidence of wage responses for wages close to the minimum wage and employers only partially comply with the minimum wage (Peréz Peréz, 2020).

On the basis of the resulting estimated formulas (6), (8) of VAR models, it can be clearly stated that there is no short-term relation of the indicators for the Czech Republic and Poland. It is found that the VAR model for the $m w$ series contains values that are not determined by the past development of this time series, formula (8). Labour demand shocks emerge as the main determinant of employment and unemployment variability in the short-to-medium run, especially in Poland and in the Czech Republic (Bukowski et al., 2013).

A statistically significant indicator in Slovakia is $I T R_{L}$, by economic verification, it is determined a contradiction with the specified assumption, formula (7). A statistically important indicator in Hungary is $I T R_{L}$, formula (9). It is an indicator that, during economic verification, does not conflict with the specified assumption. The agreement on raising the minimum Hungarian wage and reducing the tax burden of 2016 is confirmed. The lifetime tax burden on variable incomes for private-sector employees has higher income risk in all V4 countries, except Hungary using flat tax, results in less progression, primarily due to the existence of a minimum wage, which effectively serves as insurance (Vlachy, 2017). Reducing the tax burden is a much better way to reduce unemployment and improve the income situation of low-income employees' groups than increasing the minimum wage.

Making a general conclusion of a clear influence points to weaker relations between the variables examined. If we still want to find a general economic formula between the variables, we will not get to more than $10 \%$ at explanatory level, which is a low level that proves the absence of a general relation between the variables across the countries examined in the selected period. The minimum wage is used as a political tool and serves to the public interest. A higher minimum wage leads to an increase in other wage levels, which affects the amount of the average gross wage. Higher wages bring higher levies on premiums and taxes. Raising 
the minimum wage can be seen as a way of fostering economic growth and the path to raising living standards (Pernica \& Janáč, 2015). The reason for increasing the minimum wage is both a comparison of the minimum wage with the countries of the European Union (Eurostat, 2020) and the motivation of people to take up and carry out work activities. However, employing people with a minimum wage generally means lower contributions to the social and health system $\left(I T R_{L}\right)$ in relation to the payment of entitlements to these employees in the long term and an ageing population that can cause a deficit in the resources of the countries examined. Estimated formulas (6), (7), (8), (9) suggest that the influence of economic variables does not affect the increase of the minimum wage and the influence of variables is low and insignificant.

The causal relation was detected for the minimum wage and unemployment in the case of the Czech Republic and Hungary, (more in Tabs. 5 and 8). It can be argued that the unemployment effect appears to be greater for labour markets, where the minimum wage is more constricting. The negative effects of the minimum wage on employment are higher in small open countries as they are under significantly higher pressure from international competition. As the minimum wage increases, companies decide to dismiss workers due to the increase in costs and thus the unemployment increases. These conclusions are in accordance with study done in the Czech Republic, i.e. Kaderáaková and Jasová (2016) or Fialová and Myslíková (2009). Hungarian companies employing minimum wage workers experience a large increase in their total labour cost which are mainly absorbed by higher output prices and higher total revenue (Harasztosi \& Lindner, 2019). It can be concluded that for the most part they will be lower-skilled people who are paid the minimum wage or it may also apply to certain categories of workers or unemployed persons who have secured an income from the state in the amount of the subsistence minimum, in a similar amount as a minimum wage. The effect of education on incomes and social origin significantly affects the distribution of incomes, although it occurs indirectly via cultural capital and social connections (Domanski, 2019). However, this is a short-term period, the results of a larger part of the tests are statistically insignificant and do not provide us with information as to whether the unemployed have found work elsewhere. The research of GorausTanska and Towalewska (2019) confirmed the existence of wage differentials, both in raw and adjusted data, between different employment forms in Poland.

The minimum wage should ensure a higher average wage. The more distant the minimum and average wage values are, the more people will be motivated to find a new job. As demand for work grows, consumption and investment growth as a gross domestic product will increase, average wages will increase and unemployment in relation to rising employment will decrease, as confirmed also by the causal relation of Granger causality in Hungary (see Tab. 8). The development of the minimum wage is largely influenced by the institutional environment. The amount of the minimum wage in individual countries is determined for each year or multi-year period by law. The amount to be determined here is often influenced by a political decision. However, in making this policy, the government needs to base itself on the value of macroeconomic indicators. The results in models (6) to (9) confirm in some countries the influence of the tax and levy burden as one of the institutional factors. The Granger causality test (Tabs. 6, 7, 8 and 9) confirms that the amount of the minimum wage reflects the development of economic variables such as unemployment in all the countries analysed. In the case of the Czech Republic and Slovakia, another factor is the gross domestic product and consumer price index. In Poland, there is a high dependence between the minimum wage and the consumer price index and in Hungary, unemployment is the most significant. These macroeconomic variables and their development in individual years are supporting indicators of political decisions influencing the level of the minimum wage. Also, due to the consideration of these institutional aspects and according to the legislation in Hungary, Poland and Slovakia, the hypothesis $H 1$ is rejected.

H2: The average wage is adapting to the development of minimum wages and macroeconomic indicators.

An overview of research studies shows that the average wage can influence other economic indicators. The highest dependence is usually assumed between the already mentioned average wage and the minimum wage, because with an increase in the minimum wage, an increase in the average wage can also be 
expected. In the estimated formula (10), (11), (12), (13) of the average wage of the VAR model, the minimum wage affects only the average wage in the Czech Republic and Slovakia. The same conclusion is based on the model for the Czech Republic and Slovakia despite the fact that the labour markets in these countries are not completely identical (Koisová et al., 2018). Unemployment in the case of Poland, Slovakia and Hungary is formed in a quite similar way, whereas in the Czech Republic the situation on the labour markets is mainly determined by factors of different nature. In general, countries with low minimum wage tend to show lower price levels, in a study characterized by the consumer price index. In the case of the Czech Republic, which is a small country, this trend is confirmed by statistically significant indicators: minimum wage and the consumer price index, formula (10). These results are consistent with the study Kadeřábková and Jasová (2016), which was carried out in the Czech Republic.

The minimum wage should ensure a higher average wage. The more distant the minimum and average wage values are, the more people will be motivated to find a new job. As demand for work grows, consumption and investment growth as a gross domestic product will increase (as mentioned Bílková, 2020), average wages will increase and unemployment in relation to rising employment will decrease, as confirmed also by the causal relation of Granger causality in Hungary (see Tab. 8). Tab. 8 indicates the dependence of the minimum wage on the average wage and unemployment. It can be concluded that the average wage affects both the earnings of households with minimum incomes and the overall inequality in the country.

Although the average wage in the nationwide level of countries examined is increasing, in individual groups of businesses or employees, its development can be significantly volatile. The statistical significance of macroeconomic indicators may be distorted by a different methodology for determining the average wage.

In theory, the model (4) assumed that at the average wage would also increase if the consumer price index increased. Statistically significant, according to the formula (10) and (11), is the minimum wage in the Czech Republic and Slovakia. A statistically significant indicator in Hungary is $I T R_{L}$, according to formula (13). These are indicators for which, while economically verified, there has not been a conflict with the established assumptions. They are suitable indicators in the model.

Another statistically important indicator in the Czech Republic is unemployment, the consumer price index and $I T R_{L}$, by economic verification there has been found a contradiction with the specified assumptions, formula (10). As Fatula (2018) states, there is a relationship between the amount of wages and the amount of tax and social security contributions. This result explains the reduced motivation of people to work in relation to the social system, where the minimum wage with the effect of higher taxation is getting close to receiving social benefits. However, this view can have a differentiated impact on small, medium and large companies. While the effect can also be positive in large companies, an increase in the minimum wage can be devastating for small and medium-sized companies. On the other hand, for the remaining $\mathrm{V} 4$ countries, models (11), (12) and (13) did not confirm a significant statistical dependence between the average wage and unemployment, which represents a different conclusion from the Lindner and Reizer (2020) study.

Based on the results of the estimated models, it can be clearly stated that in the estimated formula (10), (11), (12), (13), (13) of the average wage of the VAR model there are selected statistically significant macroeconomic variables. The data analysed imply that the selected indicators explain the development of the average wage of the countries examined (see Fig. 1), and it is possible to predict the development of the average wage in the countries examined, as claimed e.g. Bílková (2020).

Statistically, there is a very strong relationship between the average and the minimum wage, the correlation coefficient acquires values approaching 1 (see Tab. 1). Increasing the minimum wage, provided that the difference between the two indicators increases, may also mean an increase in the motivation for long-term unemployed people to look for work.

It is obvious that economic variables have a statistically significant effect on the average wage. It can be stated that the growth of wages of employees motivates companies to a certain increase in wages in order to keep employees.

The hypothesis $H 2$ is accepted. 
The results of this study differ from some empirical studies, as those tend to be interpreted very diversely. This is also given by the fact that the difference between the minimum wage and the average wage in the countries examined is not so deep (see Fig. 1). Moreover, it is difficult to compare the starting conditions of individual researches, as the situation in each country is different, both in the stage of the economic and electoral cycle.

\section{Conclusion}

This study is intended for a better understanding of the assessment of the impact of macroeconomic indicators on the minimum and average wages of the V4 countries examined - the Czech Republic, Slovakia, Poland and Hungary. The study was aimed to analyse selected macroeconomic indicators as variables affecting the minimum and average wage. Given the available data and the nature of their influence, not all incoming variables analysed in empirical studies were selected. For economic models, there were chosen variables such as unemployment rate, gross domestic product, consumer price index and ITR . Many effects affect wage developments, and not all can be accurately expressed based on value data. Extending of the time series based on the future availability of additional data as well as increasing the number of variables or sub-regions examined can be a theme for further research in this field.

At present, a substantial influence is attributed to the minimum and average both from the employee's and from the employer's point of view. We include minimum and average wage among some of the most monitored macroeconomic indicators. The amount of minimum and the average wage is monitored not only by economists but also by the whole public.

Almost every employee is interested in how much they earn on average and how the average wages will develop in the future. The results point to a statistically significant model of average wage utilizing correlation analysis, VAR model and Granger causality. The average wage is a significant factor according to which people decide when choosing a job. It is also one of the main reasons why people are motivated to find a job. Employees pursue the highest possible wages, while employers, for whom wages are a cost, try to adjust wages. For this reason, the wage and influencing factors are often discussed topic. The research findings are mainly applicable as a justification for the development of the average wage in relation to the employers of, especially small and medium-sized companies. This segment is more vulnerable to the rising average wages.

The study also explained the minimum wage of the countries examined through modelling of time series. It was confirmed that the amount of the minimum wage is usually negotiated by a tripartite composed of representatives of government, employers and trade unions, which applies to the Czech Republic. The enacted minimum wage in relation to the percentage of the average wage is in Slovakia, Poland and Hungary. It must be taken into account that, although there is a wide range of macroeconomic indicators that can be confronted with several model concepts, each country examined has its own minimum wage setting tool. It is not appropriate to duplicate the tools for determining the minimum wage, but it is necessary to adapt to the specific conditions of the given country. The minimum wage is paid by countries to protect employees from poverty and to motivate them to go to work rather than use social contributions. However, setting a minimum wage is a complex and sensitive societal problem.

Acknowledgement: Supported by the grant No. 2020/10 "Application of Selected Exact Methods in Evaluation the Degree of Personal Income Tax Progressivity in the European Union" of the VŠB-Technical University of Ostrava and by the project "Dynamic Factors of Business Modelling". The Ministry of Education, Youth and the Sports Czech Republic within the Institutional Support supported this project and the paper for Long-term Development of a Research Organization in 2020.

\section{References}

Aaronson, D., \& French, E. (2007). Product Market Evidence on the Employment Effects of the Minimum Wage. Journal of Labor Economics, 25(1), 167-200. https://dx.doi. org/10.1086/508734

Bacik, R., Kloudova, J., Gonos, J., \& Ivankova, V. (2019). Management of Competitiveness and Economic Performance Based in the V4 countries. Marketing and Management of Innovations, 3, 73-88. https://dx.doi.org/10.21272/mmi.2019.3-06

Bajus, R., Hudáková-Stašová, L., \& Gál, M. (2015). Taxation of Income of Natural Persons in Selected EU Countries. Mediterranean 
Journal of Social Sciences, 6(3), 77-85. https://dx.doi.org/10.5901/mjss.2015.v6n3s1p77

Balcar, J., \& Gottwald, J. (2016). Wage Determinants and Economic Crisis 2008-2014: Evidence from the Czech Republic. Ekonomický časopis, 64(1), 3-21.

Bílková, D. (2020). Wage Level as One of the Most Important Indicators of the Quantitative Aspect of the Standard of Living of the Population and Selected Indicators of Economic Maturity in OECD Member. Engineering Economics, 31(3), 334-344. https://dx.doi.org/10.5755/j01. ee.31.3.23441

Blais, A., Cousineau, J., \& McRoberts, K. (1989). The Determinants of Minimum-Wage Rates. Public Choice, 62(1), 15-24. https://doi. org/10.1007/BF00168011

Broecke, S., Forti, A., \& Vandeweyer, M. (2017). The Effect of Minimum Wages on Employment in Emerging Economies: A Survey and Meta-analysis. Oxford Development Studies, 45(3), 366-391. https://dx.doi.org/10. 1080/13600818.2017.1279134

Bukowski, M., Koloch, G., \& Lewandowski, P. (2013). Shocks and Rigidities as Determinants of CEE Labour Markets' Performance: A Panel SVECM Approach. Economics of Transition, 21(3), 553-581. https://dx.doi.org/10.1111/ecot.12017

Calmfors, L. (1995). Labor-Market Policy and Unemployment. European Economic Review, 39(3-4), 583-592. https://doi. org/10.1016/0014-2921(94)00065-8

Cengiz, D., Dube, A., Lindner, A., \& Zipperer, B. (2019). The Effect of Minimum Wages on Low-Wage Jobs. Quarterly Journal of Economics, 134(3), 1405-1454. https://doi. org/10.1093/qje/qjz014

Cristea, L. A., \& Zeti, C. (2019). Study on the Incidence of Social Security Contributions on Employment and Unemployment, in the European Context. Revista Economica, 71(2), 24-42.

Czech Statistical Office. (2020). Average Wage in the Czech Republic. Retrieved January 9, 2020, from https://www.czso.cz/documents/ 10180/91917750/32018119_0503.pdf/e9b66de1220e-4d32-8329-53037da4ba05?version=1.0

Čermáková, K., Kadeřábková, B., \& Jasová, E. (2016). Influence of Institutional Factors on Structural and Cyclical Unemployment in the Countries of the Visegrad Group. In Proceedings of the 10th International Days of Statistics and Economics (pp. 315-322). Prague, Czech Republic.
Dardanoni, V., \& Lambert, P. J. (2002). Progressivity Comparisons. Journal of Public Economics, 86(1), 99-122. https://doi. org/10.1016/S0047-2727(01)00089-5

Delteil, V., Pailhé, A., \& Redor, D. (2004). Comparing Individual Wage Determinants in Western and Central Europe: On the way to Convergence? The Cases of France and Hungary. Journal of Comparative Economics, 32(3), 482-499. https://doi.org/10.1016/j.jce.2004.03.003

Domanski, H. (2019). The Effect of Education on Earnings Distribution in Poland: 1988-2013. Polish Sociological Review, 207(3), 305-321. https://doi.org/10.26412/psr207.04

Dube, A., Lester, T. W., \& Reich, M. (2010). Minimum Wage Effects across State Borders: Estimates Using Contiguous Counties. Review of Economics and Statistics, 92(4), 945-964. https://dx.doi.org/10.1162/REST_a_00039

Eurostat. (2020). Statistics $\bar{A}-\bar{Z}$. Retrieved January 10, 2020, from https://ec.europa.eu/ eurostat/data/statistics-a-z/abc

Fatula, D. (2018). Selected Micro- and Macroeconomic Conditions of Wages, Income and Labor Productivity in Poland and other European Union countries. Contemporary Economics, 12(1), 17-32. https://doi. org/10.5709/ce.1897-9254.249

Fialová, K., \& Myslíková, M. (2009). The Minimum Wage: Labor Market Consequences in the Czech Republic. Finance a úvěr, 59(3), 255-274.

Fialová, K., \& Schneider, O. (2009). Labor Market Institutions and Their Effect on Labor Market Performance in the New EU Member Countries. Eastern European Economics, 47(3), 57-83. Retrieved from http://www.tandfonline. com/doi/abs/10.2753/EEE0012-8775470303

Goraus-Tanska, K., \& Towalewska, M. (2019). Wage Differences in Poland Related to Employment Form. Ekonomista, 5, 515-451.

Harasztosi, P., \& Lindner, A. (2019). Who Pays for the Minimum Wage? American Economic Review, 109(8), 2693-2727. https://doi.org/10.1257/aer.20171445

Hungarian Central Statistical Office. (2020). Summary Tables. Retrieved January 4, 2020, from http://www.ksh.hu/engstadat

Kadeřábková, B., \& Jasová, E. (2016). Character and Intensity of the Minimum Wage Influence on Unemployment in the Czech Republic and Slovakia. International Journal of Economic Sciences, 5(1), 37-49. https://doi. org/10.20472/ES.2016.5.1.003 
Koisová, E., Masarová, J., \& Habaník, J. (2018). Regional Differences in the Labour Market in Slovakia and the Czech Republic. Journal of Competitiveness, 10(2), 104-117. https://doi.org/10.7441/joc.2018.02.07

Konečná, V., \& Andrejovská, A. (2020). Investor Decision-Making in the Context of the Effective Corporate Taxation. E\&M Economics and Management, 23(1), 111-120. https://doi. org/10.15240/tul/001/2020-1-008

Levendis, J. D. (2019). Time Series Econometrics: Learning Through Replication. New York, NY: Springer International Publishing. https://doi.org/10.1007/978-3-319-98282-3

Lindner, A., \& Reizer, B. (2020). FrontLoading the Unemployment Benefit: An Empirical Assessment. American Economic Journal: Applied Economics, 12(3), 140-174. https://doi.org/10.1257/app.20180138

Lopresti, J., \& Mumford, K. (2016). Who Benefits from a Minimum Wage Increase? ILR Review, 69(5), 1171-1190. https://doi. org/10.1177/0019793916653595

Majchrowska, A., \& Zółkiewski, Z. R. (2012). The Impact of Minimum Wage on Employment in Poland. Investigaciones Regionales, 24, 211-239.

Mendoza, E., Razin, A., \& Tesar, L. (1994). Effective Tax Rates in Macroeconomics: Cross-Country Estimates of Tax Rates on Factor Incomes and Consumption. Journal of Monetary Economics, 34(3), 297-323. https://doi.org/10.1016/0304-3932(94)90021-3

Morvay, K. (2015). The Causes of Developmental Changes in Functional Structure of Income in the Slovak Economy. Ekonomický časopis, 63(9), 906-921.

Nedomlelová, I., Staňková, L., \& Vavrek, R. (2017). Impact of Minimum Wage in V4 Countries. Journal of Applied Economic Sciences, 12(2), 332-341.

OECD. (2020). Taxes on Personal Income. Retrieved January 7, 2020, from https://data. oecd.org/tax/tax-on-personal-income.htm

Onaran, O., Boesch, V., \& Leibrecht, M. (2012). How Does Globalization Affect the Implicit Tax Rates on Labor Income, Capital Income, and Consumption in the European Union? Economic Inquiry, 50(4), 880-904. https://doi.org/10.1111/ j.1465-7295.2011.00420.x

Pauhofová, I., \& Stehlíková, B. (2018). Identifying the Relationship between Unemployment and Wage Development in the Slovak Republic. Ekonomický časopis, 66(5), 503-521.
Pavelka, T., Skála, M., \& Čadil, J. (2014). Selected Issues of the Minimum Wage in the Czech Republic. E\&M Economics and Management, 17(4), 30-45. https://doi. org/10.15240/tul/001/2014-4-003

Pérez Pérez, J. (2020). The Minimum Wage in Formal and Informal Sectors: Evidence from an Inflation Shock. World Development, 133, 104999. https://doi.org/10.1016/j.worlddev.2020.104999

Pernica, M., \& Janáč, F. (2015). Minimum and Average Net Wages in Relation to Productivity in OECD Countries. In Proceedings of the 26th International Business Information Management Association Conference - Innovation Management and Sustainable Economic Competitive Advantage (pp. 1221-1230). Madrid, Spain.

Picl, M. (2018). The Impact of The Minimum Wage on Unemployment in the Czech Republic. In Proceedings of the 12th International Days of Statistics and Economics (pp. 1411-1422). Prague, Czech Republic.

Rosso, A. (2019). Emigrant Selection and Wages: The Case of Poland. Labour Economics, 60, 148-175. https://doi. org/10.1016/j.labeco.2019.06.008

Ryckowski, M., \& Maksim, M. (2018). Low Wages - Coincidence or a Result? Evidence from Poland. Acta Oeconomica, 68(4), 549-572. https://doi.org/10.1556/032.2018.68.4.4

Statistical Office of the Slovak Republic. (2020). Statistical Yearbook 2018. Retrieved January 5, 2020, from https://slovak.statistics. sk/wps/portal/b9da354a-21ab-4c5a-b413

Statistics Poland. (2018). Statistics Poland. Retrieved January 4, 2020, from https://www. stat.gov.pl/en/

Strateg. (2020). Statistics Poland. Retrieved July 25, 2020, from https://strateg.stat.gov.pl/ dashboard/\#/

Sujanová, M., \& Sujan, I. (2002). Macroeconomic Scenarios of Development of the Slovak Economy up to the Year 2008. Ekonomický časopis, 50(5), 747-764.

Tonin, M. (2011). Minimum Wage and Tax Evasion: Theory and Evidence. Journal of Public Economics, 95(11-12), 1635-1651. https://doi.org/10.1016/j.jpubeco.2011.04.005

Tvrdoň, M. (2008). Institucionální aspekty fungování trhu práce. Politická ekonomie, 56(5), 621-642.

Vlachy, J. (2017). An Analysis of Central European Tax Systems Using Statistical Simulation. Politická ekonomie, 65(4), 410-423. 